\title{
Entrevista com Gilberto Mendonça TELES
}

Entrevista a Marcos Caldeira Mendonça, para o jornal $O$ TREM, de Itabira, MG, em 30.6.2012

\section{I - Contatos}

Em 03/03/12,

Marcos Caldeira<otremitabirano@yahoo.com.br> escreveu:

Caro poeta Gilberto M. Teles, bom dia, levando em consideração que O TREM só entrevista quem tem o que dizer; partindo da premissa de que cada vez mais precisamos ouvir os bons poetas; pergunto: o senhor tem coragem de perder um tempinho de vida para dar uma entrevista ao jornaleco da terra de Drummond?

Dez, doze perguntas, pela internet mesmo, sem pressa, na calma mineira.

Temos entrevistado muita gente boa Brasil e mundo afora, mas ainda não papeamos com o senhor. Queremos corrigir essa lamentável falha. Topa?

Marcos Caldeira Mendonça O TREM Itabirano (31) 3835.1329 Itabira / Belo Horizonte. $M G$ 
Sábado, 3 de Março de 2012, 20:04, Gilberto Mendonça Teles $<$ gilmete@globo.com>escreveu:

Topo, Marcos. Toda vez que recebo o seu jornal, encontro sempre um tempo de passar os olhos e ler o que mais me interessa. Estive duas vezes em Itabira. Mande as perguntas. Como tenho bastante compromisso neste mês, creio que só depois do dia 25 poderei tratar das respostas. Abraço do Gilberto

No mesmo dia: Ótimo, Gilberto, vamos sem pressa, na calma. Vou coletar as perguntas com a patota da redação e the mando brevemente.

Abraço.

Marcos Caldeira Mendonça

$*$

Poeta,

queremos muito ter a sua palavra em nosso jornal. Seguem novamente o questionário e nosso abraço.

Caro poeta Gilberto Mendonça Teles, boa noite, seguem as perguntas para a nossa combinada entrevista para o jornal O TREM Itabirano, que tem a mania, já quase exótica na imprensa, de só puxar 
papo com quem tem o que dizer. Papeamos com um mundão de gente e agora queremos corrigir a falha de nunca tê-lo entrevistado.

Não se preocupe com o tamanho das respostas. Temos o papel e a tinta que for preciso. Outra coisa: publicaremos tudo na integra, jamais cortamos a fala dos nossos entrevistados. Claro, sabemos que o senhor é um homem muito ocupado e saberemos esperar.

Um abraço e vamos às perguntas [Transcritas em itálico antes das respostas]. Obrigado,

Marcos Caldeira Mendonça, Editor dO TREM Itabirano

\section{II - A entrevista ${ }^{*}$}

\section{"Cachaça ruim essa de Itabira"}

Fez triiimmm o telefone do apartamento de Carlos Drummond de Andrade. O itabirano atendeu e ouviu este por-favor: jogue fora aquela garrafa com cachaça de Itabira, pois é horrivel, não desce nem com limão. A voz era do poeta, ensaísta, crítico e professor goiano Gilberto Mendonça Teles, possivelmente vítima de um golpe que ainda vige no comércio itabirano.

Na primeira visita à cidade de Drummond, o autor de Saciologia Goiana almoçou num restaurante onde lhe serviram boa cachaça.

* Entrevista a MARCOS CALDEIRA MENDONÇA, para o jornal O TREM, de Itabira, MG, em 30.6.2012. Foi transcrita em A poesia na visão de Gilberto Mendonça Teles, dissertação de Mestrado de LUCILENE MACIEL DE OLIVEIRA VIDAL, defendida na PUC de Goiás, em 2014, sob a orientação da Profa. Dra. Maria de Fátima Gonçalves Lima. No final dessa dissertação aparece o poema "Mestre", do Prof. JosÉ FERNANDES, que a examinou, razão por que ele aparece na Fortuna Crítica, abaixo. 
Gostou e comprou três garrafas. Guardou a dele e deu as outras de presente, uma para o autor de Boitempo. Quando Gilberto Mendonça Teles abriu, para beber com um poeta maranhense que o visitava no Rio de Janeiro, ó desagradável surpresa. Ligou logo para Drummond, avisando-o sobre a péssima cachaça de Itabira.

Quase 30 anos depois, O TREMlevou a Nezito Sampaio, tarimbado dono de armazém em Itabira, o caso da cachaça que feriu o paladar de um poeta e por pouco não arranhou a garganta de outro. $O$ goiano caiu no golpe da provadinha, suspeita Nezito Sampaio. Um comerciante oferece a um freguês viajante uma amostra de um bom produto - cortesia da casa. Estimulado, ele compra várias unidades para viagem. Longe da vista da vítima, o escroque embrulha uma mercadoria barata, de má qualidade. Simples, certeiro e bem sacana.

A seguir, em entrevista exclusiva, Gilberto Mendonça Teles fala também sobre livros, abdução, Goiás, Minas, a prostituta que pendurava poemas dele na parede, o médico que não cobrou do poeta e outros assuntos. "O Brasil só atingirá a sua maturidade politica e econômica se cada estado, municipio, distrito, povoado, biboca do mato dentro adquirir a consciência da sua sustentabilidade cultural", diz. 


\section{Perguntas e Respostas}

1. Gilberto Mendonça Teles ia passando de madrugada por Ipanema e, ploft, foi abduzido para o planeta Attynk, a bordo da reluzente nave placa $T W g W 2 s r$. Lá chegando, foi recepcionado pela simpática etezinha Nikkolli: "Olá, poeta, seja bemvindo, vamos tomar um chazinho sideral. Mas me conte, como é o seu país, o Brasil? É bom viver lá?. O que o senhor diria a Nikkolli?"

1. Não houve muita surpresa na abdução, sobretudo nas altas horas de Ipanema, perto do Pavão Pavãozinho, onde há sempre um pavão misterioso levantando voo para algum planeta ainda por descobrir-utópico e ucrônico como a Ilha dos Bem-Aventurados ou a dos Amores, um daqueles paraísos que Luciano de Samósata soube parodiar no início do cristianismo. Só num lugar assim, um ar-tesão como o Gilberto poderia encontrar uma E-tesinha tipo Nikkolli, capaz de ir logo lhe oferecendo um pouco de chá das cinco ("Chá de poejo para o teu desejo / chá de poaia e rabo de saia”). Combinamos que só depois do chá conversaríamos sobre o meu país, o Brasil, e sobre a vida por lá. Pedi-lhe que, para o sentido maior da nossa intimidade, era preciso abolir o título honorifico de "senhor". Assim, depois do que disse à E-tezinha (e que não fica bem publicar aqui), o poeta começou a explicar que o seu país tem a forma de harpa, por isso nele há sempre música, sendo muito bom viver por lá. O problema é que há muito tempo o instrumento anda desafinado, na corda política, na da educação, na da seriedade administrativa, produzindo sons estridentes como da corrupção. Nikkolli se sentiu triste e me pediu para continuarmos outro dia. Prometeu vir tomar um chopinho comigo em Copacabana. 
Mas antes que eu voltasse, Nikkolli pegou um livro, Linear G, 2011, e me leu trechos do poema "Formação da Consciência Nacional":

É só ir expulsando os índios, matando-os se for preciso. Acasalar-se com as negrinhas e plantar alguma roça para povoar e garantir a "legitimação" da posse.

Fazer santo de pau oco para esconder ouro e diamante assim como os vice-reis fizeram com a Coroa.

Fica desde logo instituída a lei do mais esperto.

No início do século XX os seringalistas punham pedras para aumentar o peso da borracha e ainda hoje nas feiras se escondem as frutas podres no meio das sadias para enganar os fregueses e nalgum lugar do Distrito Federal tudo se faz e se desfaz et coetera e tal.

Leu depois uma estrofe de "O Estilo", onde se diz que há por lá (aqui)

$A$ arte do sim pensando o núncara, garantindo a eleição com asa adúncara, jeitinho de encobrir com véu e rábula e pôr dentro da cueca alguma fábula ou lixo ou dólar, toda coisa lúbrica que ninguém sabe nem viu nesta república. 


\section{2. [O senhor] Você me disse por e-mail que esteve em Itabira duas vezes. Quando foi, o que veio fazer aqui, qual sua impressão da cidade, algo o marcou ou nada em especial? Ficou alguma coisa [no senhor] em você dessa vinda à cidade de Drummond?}

É verdade, no nosso primeiro contato lhe falei das duas visitas que fiz a Itabira, cidade que todo leitor obstinado da obra de Drummond deseja conhecer. Na primeira vez, 1983, eu havia alugado um apartamento em Belo Horizonte com o fim de acompanhar meu filho durante seus dois transplantes de córnea. À espera dos acontecimentos e tendo já terminada a leitura do livro que levei para revisão, aceitei o convite de uma amiga, professora da Faculdade de Letras, para visitar Itabira. Fomos no automóvel dela. Andamos pelas ruas, tentando identificar as possiveis referências de alguns poemas. $\mathrm{Na}$ hora do almoço nos indicaram um restaurante. Antes de escolher os pratos, pedi um aperitivo, uma cachacinha local. $O$ dono do restaurante nos serviu uma muito boa, e tão boa que comprei logo três garrafas: para mim, para a professora e outra para levar ao Drummond. Quando voltei ao Rio, telefoneilhe e marcamos uma visita: fui com a garrafa de pinga, feliz por poder comentar com ele a visita à sua terra. Dias depois, foi à minha casa um poeta do Maranhão. Para brindar a sua visita abri a garrafa que havia trazido de Itabira - era muito ruim, álcool puro, impossível de beber, nem com limão. Penso que o dono do restaurante se enganou e me vendeu outro tipo diferente da que trouxe para provar... Telefonei a Drummond e pedi-lhe que jogasse fora a garrafa que lhe dei. Telefonei também à professora de Belo Horizonte. Enfim, apreendi que o certo é experimentar sempre ou como disse Camões: "Melhor é exp'rimentá-lo, que julgá-lo: / Mas julgue-o, quem não pode exp'rimentá-lo”.

No livro Plural de nuvens (1984), o poema "Parêntese" (alusão à serra do Curral) documenta essa viagem, chegando a citar o nome de Itabira: 
Talvez eu não devesse estar aqui de mãos vazias, remoendo lembranças, puxando pelas palavras mais simples como se estivesse catando pulgas no pelo-sinal dos verbos e verbetes.

Talvez eu não devesse estar aqui como um homem cordial, pensando na ho(n)ra do primeiro enfarte e esperando furar esta fila de córnea para os olhos do meu filho.

Talvez devesse estar aproveitando este fim de semana, conhecendo Itabira, vendo o rio das Velhas e tentando surpreender nas cavernas o claro enigma da grande poesia.

Talvez fosse melhor abrigar-me no parêntese da serra e ficar contemplando o transplante de nuvens e neblinas, como se depois de mim, o dilúvio e a solução cortada de soluços.

Fui outra vez à cidade de Itabira, em 31 de outubro de 1995 , para dar um "Depoimento sobre Drummond" na TV Cultura local. Falei sobre o sentido de transformação e permanência ao longo de seus livros, enaltecendo assim a atualidade de sua criação poética. Fui convidado pelo Secretário Municipal de Cultura, de cujo nome não me lembro agora. Sei que dormi num bom hotel e pude curtir melhor a simpatia da cidade que, pela data, festejava o aniversário do poeta que um dia me escreveu a respeito de umas anotações que eu fazia sobre a Seleta Drummond, com textos de prosa e verso escolhidos por ele e comentados por mim. Uma das perguntas que lhe fiz por carta era 
sobre um verso que não encontrei no texto escolhido. E Drummond assim me respondeu (Cf. A Plumagem dos nomes: Gilberto 50 anos de poesia, 2007):

A "pedra de ferro, futuro aço do Brasil" deve ter sumido de todas as edições posteriores a SM por dois motivos. Primeiro, porque o ferro de Itabira não é beneficiado lá mesmo, e vai todo, ou quase todo para o estrangeiro. Segundo, porque o verso é um tanto enfático e menos acomodado ao tom elegíaco do poema. Meditando sobre ele agora, porém, resolvo restabelecê-lo. Afinal, brotou das entranhas, em hora de nostalgia, justamente com os demais versos... e acabei me reconciliando com ele, graças a você.

Por falar em pedra, é bom explicar o sentido que dou ao famoso poema "No meio do caminho". No meu livrinho Caixa-de-fósforo, depois de um poema aos 70 anos de Drummond (que ele me agradeceu numa carta), escrevi em nota de rodapé que "O poeta se casou em 1925. Em 1927, nasce e vive alguns instantes seu filho Carlos Flávio. Em julho de1928, a Revista de Antropofagia publica "No meio do caminho", onde, a meu ver, a palavra pedra deve ser lida como hipértese de perda: a "pedra" tumular a assinalar a "perda" do filho.

\section{Este é um super-ano Carlos Drummond de Andrade: 110 anos de nascimento do poeta, 25 anos de morte, festejos na Feira Internacional de Literatura de Paraty, relançamento da obra do itabirano pela Companhia das Letras, etc. Há alguma faceta ainda carente de estudo na obra dele ou tudo já foi escarafunchado?}

Numa conferência na Universidade de Lisboa, em outubro de 2007, sobre "O privilégio de ler Drummond", falei lescrevi que a obra de um grande poeta é algo que não se entrega totalmente e sempre permanece desafiando as gerações de críticos e estudiosos. Assim, a riqueza, a 
complexidade e a força simbólica de uma obra como a de Drummond constituem um desafio permanente. E só a soma futura dos livros, monografias, ensaios e das interpretações poderá fornecer, se não a totalidade, pelo menos uma visão das principais tendências temáticas, técnicas e estilísticas de sua grande obra literária. Se esta é a opinião dos teóricos e estudiosos, não deixa de ser também, por outro ângulo, a de um poeta como Drummond que, num depoimento pessoal (Cf. Retórica do silêncio, que ele conheceu), me afirmou estar convencido de que o poeta trabalha sempre a mesma obra, como se houvesse um fundo permanente (o seu "armazém do factivel"?), sempre retomado e expresso diferentemente pela vida afora. Cada poema, cada livro, cada obra retoma e acrescenta algo diferente que a verdadeira crítica (de agora ou do futuro) tem o dever de avaliar, independente das festividades em torno dela.

Assim, meu caro Marcos, com relação à sua pergunta, nem tudo foi escarafunchado ainda e muita coisa que o foi precisa com o tempo ser "re-escarafunchado" por outros talentos críticos, à luz de novas teorias e fora dos entusiasmos universitários que se arrogam "donos" da obra do poeta, sem acrescentar quase nada de valor crítico no que escrevem sobre ela.

4. Temos aqui em Itabira um governo obscurantista, inimigo dos livros, que destruiu três bibliotecas e trata a leitura a $\operatorname{socos}$ e dentadas. Não quero incomodá-lo com fracassos nossos, que precisam ser resolvidos por nós mesmos, no grito e no voto, é só gancho para esta pergunta: qual a importância dos livros, da leitura, no desenvolvimento de uma cidade, de um estado, de um país?

Como leio O Trem sei do esforço e da independência do seu jornal no sentido de iluminar (no iluminismo da atualidade) a vida 
pública de sua cidade e região, conscientizando-a para que, passado o tempo noturno (que sempre passa), os valores culturais da arte e da literatura encontrem o seu renascimento. Foi sempre assim: o romance só apareceu depois que o símbolo totalitário se democratizou e o imaginário individual pôde ser expresso como arte e como literatura. Creio que o país, o nosso por exemplo, só atingirá a sua maturidade política e econômica se cada estado, cada município, distrito, povoado, cada biboca do mato dentro adquirir a consciência da sua sustentabilidade cultural (palavra da moda, mas filosoficamente correta). E como se chegará a essa consciência? Pela educação, pelos livros, pela construção de uma inteligência que sustente a esperança numa vida melhor. Eu acredito nisso e, como exemplo, já remeti para a cidade de Bela Vista de Goiás (onde nasci) cerca de dez mil volumes.

5. Gilberto Mendonça Teles é nomeado Ministro da Cultura. O Brasil o chama, não vale pedir exoneração. O que faria para ampliar o número de leitores no Brasil? (X) a literatura muda o mundo; ( ) a literatura não muda o mundo. Onde [o senhor] você põe o xis? Por favor, explique a opção marcada.

Para mim a Literatura muda o mundo, como começou a mudar desde que a escrita foi introduzida na Grécia [VII a.C.] e os poemas de Homero motivaram o aparecimento dos poetas líricos e trágicos, na grande paideia que civilizou o mundo ocidental. Penso que a Literatura na expressão "mudar o mundo" deve ser entendida como instrumento de conscientização: ela ajuda a dar ao homem o conhecimento, o saber necessário para que ele se situe condignamente no mundo. 


\section{Os jovens hoje, tirando aí os tais gatos pingados, não leem poesia. A culpa maior é da escola brasileira?}

Eu não penso assim: acho que mais do que os "tais gatos pingados" muita gente lê poemas, o que não quer dizer que leem poesia. É que sempre se falou assim, mas ninguém fez ainda uma pesquisa séria a este respeito. Claro que essa pesquisa não deve ser feita apenas nas editoras, grandes e pequenas. Sei que há muita gente lendo, nova e velha. É preciso ver também as produções independentes, sobretudo agora com a facilidade de impressão e com a diversificação da leitura. É possível que hoje a escola, querendo parecer (não ser) moderna e fascinada pelo computador, venha descurando a leitura dos bons poemas. Mas não esqueçamos que poetas como Manuel Bandeira e Drummond só começaram a ser lidos na escola depois dos seus 40 anos. Pela circulação do livro entre os escritores [diariamente entra um livro na minha casa], pode-se ver a continuidade da leitura...

\section{Nenhum ser humano jamais conseguiu ou conseguirá ler todos os bons livros que há. Não há tempo para tal tarefa. Isso o angustia?}

Claro que sim, tal como deve ter angustiado Harold Bloom: a angústia da leitura é uma doença da modernidade, embora no fim do século XIX Mallarmé tenha dito que leu todos os livros, o que é compreensivel. O que mais me angustia não é a falta de tempo, mas a perda inútil de tempo, leituras inúteis que somos obrigados a fazer em livros, jornais e computadores. A angústia aumenta depois que se sabe que Carlos Drummond de Andrade, em "Apelo a meus dessemelhantes em favor da paz", disse que está “atrasadíssimo nos gregos”, pedindo 
angustiado: "Ah, não me tragam originais / para ler, para corrigir, para louvar / sobretudo para louvar”. Isto é a angústia.

\section{Se pudesse escolher um poeta brasileiro morto para papear por meia hora, quem seria e sobre o que gostaria de conversar com ele?}

Como na Eternidade o Tempo parece ser outro ("E como ficou chato ser moderno, agora serei eterno”, diz um verso de Drummond), não tenho dúvida de que gostaria de conversar com Manuel Bandeira, não apenas meia hora: leria com ele os seus poemas para extrair deles a lição da simplicidade, do apuramento técnico e da luta que ele teve consigo mesmo para fazer o seu verso livre ficar tão próximo da linguagem comum sem perder a poesia. Acho que Drummond também gostaria de ficar batendo papo com ele, aliás já o fez na "Ode no cinquentenário do poeta brasileiro".

\section{Por favor, fale sobre a importância da leitura, do seu amor pelos livros. É muito importante ouvi-lo.}

Acho que tudo que venho dizendo (e mais o que não disse) remete para a "importância da leitura", para o "meu amor pelos livros" $e$ para o que eles têm sido na minha vida intelectual e material. $O$ importante agora poderia ser fazer falar o que ficou sem voz no silêncio ou nas entrelinhas do que tentei dizer até agora. O leitor que cave o chão do discurso. Lembro-me que Drummond, a respeito das entrevistas colegiais, dizia que toda a sua vida estava na sua obra. 
10. Li uma história, não sei se procede. Em Brasília, o escritor Cyro dos Anjos virou-se para o senhor e, jocosamente, perguntou: "Goiano, lá em Goiás se estuda literatura?" O senhor ficou ofendido e deu ao mineiro esta resposta: "Não estudamos muito bem, não, mas lemos muitas coisas ruins que escrevem por aí. Há pouco lemos um livro do senhor por lá". É verdade? Qual foi a resposta do autor de Amanuense Belmiro?

É verdade, sim senhor. Em 1962, já professor da Faculdade de Filosofia (Católica) em Goiânia, fui convidado para pertencer ao quadro de professores da nascente Universidade de Brasilia, a $200 \mathrm{~km}$ de Goiânia. Ao participar da primeira reunião para a distribuição dos horários e das turmas, conheci o escritor Cyro dos Anjos, diretor do Departamento de Letras, onde eu ia trabalhar. Ele me disse que eu trabalharia com lingua portuguesa, embora tivesse sido convocado para a área de literatura. Disse-lhe que gostaria de começar com a literatura. Foi ai que ele, querendo fazer graça, me fez, muito sem graça, a tal pergunta, a que dei a resposta acima, relembrada no poema "In illo tempore" do meu livro Linear $G$, na parte denominada ÁRVORE DO CERRADO. Coincidentemente, a UnB era mineira, de Montes Claros, como o reitor Darcy Ribeiro e o Diretor do Dep. de Letras, Cyro dos Anjos, não se falando em outros professores que flanavam por lá.

A vida constrói, entretanto, as suas voltas. Saí de Goiânia para Lisboa, onde estive mais de ano e fui logo convidado pelo Itamaraty a trabalhar em Montevidéu. Depois de quatro anos, recebi o AI-5 e achei melhor não voltar a Goiânia, onde nada se fazia sem consultar Brasília. Vim para o Rio de Janeiro, a cidade mais democrática do Brasil, onde estou há quase quarenta anos. Um dia recebo um telefonema de Afrânio Coutinho me convidando para ir dar um curso sobre poesia na Universidade Federal do Rio de Janeiro. Lamentei, 
dizendo que estava cassado, ao que ele retrucou: Venha assim mesmo, ninguém aqui está querendo dar curso de poesia. Fui e encontrei lá o professor Cyro dos Anjos: a sua timidez, a sua voz suave e a sua angústia de perfeição literária. Pois não é que o diretor do Departamento de Letras me convoca para saudar o professor Cyro dos Anjos, nos seus oitenta anos. Aceitei, com muita honra. Tive o bom senso de não aludir ao "nosso" passado nos primeiros tempos de Brasilia. Creio que ele nem se lembrava mais daquele rapaz audacioso que causou risinhos abafados entre alguns efebos daquela troupe. Teci comentários elogiosos à sua obra e, mais tarde, na PUC, orientei um bom doutorado sobre o Amanuense Belmiro.

\section{Pergunta ao crítico Gilberto Mendonça Teles: O que perde uma pessoa que não lê Gilberto Mendonça Teles?}

Não perde nada, nem mesmo a possibilidade de me conhecer. Mas o diabo é que muita gente já deve ter perdido tempo com o meu lado crítico e até com a minha obsessão pela poesia. No fundo, as

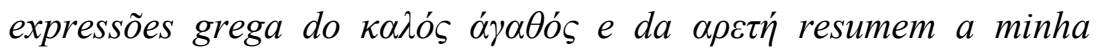
filosofia de vida literária.

\section{2. É verdade que havia uma prostituta que colava seus poemas [do senhor] na parede do quarto dela, na zona?}

É sim. Eu tinha dezenove anos e Celina vinte e quatro. Morava sozinha, numa pequena casa na Vila Operária, perto da Zona. Quando chegava o fim do mês e recebia meu dinheirinho, ia visitá-la. Ela abria uma garrafa de vinho, pois sabia que eu não gostava de cerveja e conversávamos até de madrugada. Eu frequentava a Faculdade de Direito e já tinha um bom emprego (por concurso). Escrevia muito e 
de vez em quando publicava um poema nos jornais de Goiânia. Um dia ela me mostrou na parede de seu quarto, ao lado de uma estampa de santo e de alguns retratos, um poema em que eu falava de amor. E sempre que ia lá (no fim do mês) encontrava o recorte de um novo poema. Penso que acabou gostando de mim e não me cobrava nada, nem o vinho. Confesso que fiquei muito feliz por ver os poemas na parede do seu quarto. Mas essa felicidade foi a causa de nossa separação. Comecei a gostar dela e cheguei a lhe falar em casamento. Ela meigamente me disse: Na outra vez vamos conversar sobe isso. Achava estranho que ela me proibisse de ir lá no fim de semana, a partir de sexta-feira. Depois dessa conversa interrompida, nem cheguei a esperar o fim do mês e, numa terça-feira à noite, lá estava eu com um novo poema na mão. Leu-o e começou a me dizer: Você sabe que esta casa não é minha? É do fazendeiro que vem no fim de semana: ele também pensa em se casar comigo e sabe de você, acha até que você é uma boa companhia para mim. Você é ainda muito novo, a sua vida vai lhe trazer outras alegrias, inclusive um casamento muito melhor. Fiquei p. da vida e nunca mais voltei lá. No caminho de casa (morava com meus pais) fui pensando o poema "Vida" (hoje em Planície, 1958), cuja última estrofe tenta "refletir" a minha angústia daquela noite:

A vida que chega e foge

sem madrugada e sem tarde,

fora demais possuí-la, tê-la entre os dedos, amá-la, senti-la a cada momento, depois perdê-la no tempo sem conhecê-la jamais!

Marcos, você puxou a história, agora aguenta o final. Dez anos depois, no lançamento do livro Pássaro de pedra, levantei os olhos do livro que estava autografando e vi duas mulheres bem vestidas saindo 
da livraria. Logo que terminei o autógrafo, pedi licença e fui perguntar ao livreiro pelas duas mulheres: Não sei quem são, mas compraram seu livro e saíram pela direita. Eu saí atrás, alcancei-as, pedi licença e vi que era Celina. Desculpou-se por não haver pedido o autógrafo: não queria me constranger. Tirou um cartão da bolsa e me disse: Espero o seu autógrafo neste endereço. Meu marido vai gostar de conhecer você. Saí como um cachorro com o rabo entre as pernas.

\section{3. É lindo isso. Onde foi, quando foi, como ficou sabendo?}

Acho que tudo está dito acima. Só não compreendi o seu "como ficou sabendo?" Eu é que deveria perguntar-lhe: Como ficou sabendo disso? Gostei que você achasse lindo. Lindo foi também o gesto elegante dessa mulher que nunca mais vi.

\section{Vivemos uma época superabundante em informação e também da enganação travestida de informação. Qual a sua compreensão [do senhor] sobre esse assunto?}

Os meios de informação além do jornal (o computador, a internet, o e-mail e o celular - só uso esses) aumentaram em dez anos a minha capacidade de produção intelectual. Eu me iniciei no computador quando fui professor na Universidade de Chicago, em 1991, e de lá para cá tenho tirado todos os proveitos dele. Quanto ao e-mail, lamento apenas a quantidade de lixo que nos chega diariamente. É preciso saber selecionar para responder: se não, perde-se muito tempo com ele. A televisão brasileira não é capaz de veicular notícias positivas, mesmo quando denunciam a corrupção em Brasília, os crime do Rio de Janeiro e São Paulo. O índice de audiência se marca por esses temas. E a audiência tem a ver com o nível de 
educação do povo brasileiro, logo o "melhor" é deixar o povo a ver navio ou futebol. Há no Rio de Janeiro (como em toda capital) um grupo de radialistas que perdem diariamente horas e horas discutindo o óbvio dos problemas dos clubes e dos jogadores de futebol, com muita gente boba que os ouve, que nem eu... Voltando ao e-mail, vai um poema sobre ele:

\author{
E-MAIL \\ por artes do saci ou da internet \\ meu nome se encolheu - virou gilmete \\ para evitar o golpe da mão-boba \\ depoisdonome colocar@ \\ e continuar mas sem mudar de tom \\ a conexão de globo ponto com \\ como não gosto que me grite ou berre \\ nem é preciso digitar br
}

\title{
15. [O senhor] Você também é professor. Todos sabem que a educação é fundamental para tirar o país do atraso. Por que a questão do ensino no país ainda é uma vergonha, com professores mal-remunerados, escolas aos pedaços e tantos outros entraves? Como vê a questão, você [o senhor] que conhece o problema de dentro?
}

Muito do que você afirma, questionando, está implícito em respostas anteriores, de maneira que devo apenas concordar, pondo ênfase num dos problemas do ensino - o da pesquisa e criticar o sentido de horizontalidade (de expansão) que vem caracterizando a universidade brasileira. Há muitos anos que as Federais têm um objetivo nacional: criar campi, estender-se pelo Estado. Quanto mais 
"campos" tiverem, mais importantes aparecem às verbas do MEC. Com isto não conseguem aperfeiçoar seus professores nem modernizar os instrumentos pedagógicos, mas contam com a "vantagem" de novos centros universitários na região. Por outro lado, por exigência da CAPES os professores têm de pesquisar e produzir continuamente. $O$ resultado são estudos apressados, com pesquisa livresca para os congressos anuais, sem ou quase nenhuma contribuição para o pensamento científico nacional. Para resolver o problema, os últimos governantes trataram de criar mais universidades, em vez de aperfeiçoá-las. A verticalidade vai cedendo lugar à chamada horizontalidade "democrática".

\section{6. É importante ouvir gente séria sobre este assunto crucial no Brasil: televisão. A TV Brasileira - refiro-me aos grandes canais - está insuportável. Como desburrificar o público que a TV burrifica?}

Penso que já dei minha opinião sobre isso na questão $n^{\circ} 14$. Ainda que de passagem, falei sobre a TV no Rio de Janeiro, "cuíca" do Brasil. Sou amigo de um homem de televisão. Quando lhe ponho a questão de programas culturais, por exemplo, ele vem logo com o indice de audiência: se cai, não presta... Esta é a "filosofia". Eles têm consciência de que o melhor é continuar como está, apenas com mudanças internas. Em time que está "ganhando" (dinheiro), não se mexe. 


\section{Como lida com este aço perfurocortante chamado saudade?}

Para mim um bom remédio é a poesia: um bom poema (que se lê ou se escreve) reduz o colesterol, elimina as tensões do corpo $e$ aumenta as percepções da alma - o espirito, sem as dimensões de tempo e espaço, presentifica as lembranças, os acontecimentos e, por aí, o que era saudade se torna vivência - a vida bem ou mal vivida. Não é mais ou menos isto que William Wordsworth sugere quando diz que "Poetry is emotion recollect in tranquility"?

18. Ninguém escreve para ficar escondido e fracassar. Quem escreve quer fazer sucesso, quer ganhar dinheiro para poder conhecer o mundo e poder escrever mais e melhor; quer ser lido por muitas pessoas; quer ser admirado e respeitado como autor inteligente, sagaz, culto, que escreve textos que enriqueçam as pessoas. Como é para [o senhor] você essa busca?

É bonito o que você falou, mas há controvérsias... A primeira coisa é saber que a questão é redutora - diz respeito a quem escreve literatura (poesia, conto, crônica, romance, teatro e crítica e história literária, por que não?). Há quem escreve por passatempo, para se ver narcisisticamente no espelho da escrita, nem pensa em publicar, nem pensa em glória ou fracasso. Pode acontecer, entretanto, que o danado sabe mesmo escrever, tem talento: um dia alguém descobre, ou não. Não vou dar exemplo, mas existe. Concordo com o desejo (às vezes inconsciente) do sucesso. Quanto a ganhar dinheiro, não sei não, embora exista o que chamo "salário indireto" motivado pela aura da poesia, que a literatura muitas vezes proporciona. Exemplo: fui convidado a ser professor na Universidade de Chicago por causa do meu livro sobre as vanguardas. Outro: Por causa da poesia (eu havia 
ganhado o prêmio "Olavo Bilac" da ABL com o livro A raiz da fala), Afrânio Coutinho me convidou a ser professor de poesia na UFRJ.

$O$ verdadeiro escritor (poeta, ficcionista, ensaísta) é sempre tocado pela aretê, palavra grega da qual se originou o termo arte: o termo grego conserva, desde Homero, o significado original de fazer o melhor que se pode, de "escrever mais e melhor" como na sua afirmação. Acho que tudo o mais que você disse tem sentido. Afinal, essa busca tem a ver com a famosa resposta de Paul Valéry, que não me canso de citar: Perguntaram-lhe se ele acreditava na inspiração: "Acredito que os deuses ou demônios nos dão o primeiro verso. Cabe a nós fazer o segundo", respondeu. Um bom tradutor mineiro (Onestaldo de Pennafort) acrescentou: "Mas é preciso corrigir também o primeiro verso". Aí está o significado maior do sentido da Arte.

\section{9. [O senhor] Você tem uma trajetória já de décadas. Conte-nos, por favor, uma história marcante bacana, bacana, inspiradora, vivida pelo senhor na estrada das letras.}

Quase sessenta anos do primeiro livro publicado, quase sessenta livros, no Brasil e no exterior, sempre fiel a dois gêneros (poesia e críticalensaios), por enquanto. Você me pede uma "história marcante". Penso que esta é marcante, pois legitima a permanência e o valor social da poesia. É a história das córneas, dos dois transplantes. O médico do Rio achou que o problema dos olhos do meu filho devia ser resolvido no Hospital de Belo Horizonte, isto em 1983. Arranjei dinheiro, abri uma conta num banco de lá (os cartões de crédito não estavam popularizados), aluguei um apartamento mais perto do hospital, pois era preciso esperar a doação da córnea. No 
segundo dia de espera fui ao hospital e conheci o Dr. Paulo Galvão, que ia operar o Antônio. Na conversa, falamos de poesia: ele tinha na gaveta o meu livro A raiz da fala, que acabava de ganhar dois prêmios. No final de tudo, quando fui acertar a conta na tesouraria, a moça me disse: Aqui está escrito que o senhor não tem de pagar nada. Fui procurar o médico e ele: Poeta sério não paga. Não é preciso falar da minha dupla felicidade - a do sucesso do transplante e o prêmio mais valioso dado pela poesia.

\section{Há uma famosa frase: “O México está longe de Deus e perto dos Estados Unidos”. Goiás está perto de Minas Gerais. Isso é bom ou mau para Goiás?}

A frase, se é famosa, não me parece correta para um país que tem o culto da Virgem de Guadalupe. Mas vale pelo sentido de humor, sobretudo quando se pensa nos mineiros que saem do México para os Estados Unidos. A frase tem a ver com um poema em prosa do Mário Quintana: "A morte, simples mudança de estado: uma coisa assim como quem sai do Rio Grande e entra em Santa Catarina”. [Poder-seia inverter a frase de Quintana: "A vida, simples mudança de Estado: uma coisa assim como quem passa por Minas para entrar em Goiás".] Quanto à pergunta, na parte final da boutade, lembro que o mesmo bandeirante que fundou Ouro Preto foi dez anos depois fundar a cidade de Vila Boa, hoje Cidade de Goiás, que acabou dando o nome a todo o Estado. O topônimo Goiás significa na lingua dos seus indígenas "gente parecida". Mas parecida com quem? Com os mineiros que foram para lá, tomando não só uma parte do Estado (Araguari, Araxá), como acabaram ocupando todo o sudoeste do Estado, deixando até cidade com o nome de Mineiros. Talvez seja por isso que é a região 
mais rica de Goiás e foi de onde (Jatai) Juscelino Kubitscheck acordou para a ideia de Brasília. Talvez ai esteja a razão porque Drummond falou de "certo remorso de Goiás / Goiás a extinta pureza".

Pelo que acabo de narrar, a proximidade teve o seu lado mau e tem agora o seu lado bom. Como eu vivo há 40 anos no Rio, toda vez que vou a Goiás, de carro (três a quatro vezes por ano e mensalmente de avião), tenho um prazer muito grande em atravessar o território mineiro, pois sei que logo chegarei ao goiano. Deixando de lado este tom humorístico, gostaria apenas de lembrar que o meu livro Arte de armar (que arrebatou um grande prêmio dos mineiros) tem muito da essência cultural de Minas Gerais, chegando a dizer que "O mim de Minas pesa / mineral e noturno”, alusão talvez a alguma musa morena de Cláudio Manuel da Costa. Por falar em poesia, nas três maiores cidades de Minas Gerais - Belo Horizonte, Juiz de Fora e Montes Claros - estudam-se os meus poemas. Não é à toa que gosto de poetas como os dois Alphonsus (pai e filho), Drummond, Emílio Moura, Henriqueta, Affonso Ávila e muitos outros, menos do vanguardismo ruim dos mais novos.

\section{O senhor se irrita quando associam Goiás às duplas ditas sertanejas?}

Nada disso. Sempre gostei de música, dos clássicos e dos clássicos sertanejos. Dos novos, acho que vale a pena ouvir alguns textos de Leonardo. Gosto também da piada dos dois cornos goianos que, para se consolarem, se juntam e formam uma dupla sertaneja. Eu já disse num poema de Saciologia goiana que até já andei pondo chifre nas boiadas de Goiás. 


\section{Digamos que um goiano inventou uma máquina pela qual é possível falar e ser escutado por todos os brasileiros. Se fosse usar essa estrovenga para falar durante um minuto, o que todos escutaríamos?}

Possivelmente textos de Hugo Carvalho Ramos, Bernardo Élis (lido por Guimarães Rosa) e José J. Veiga. Nos meus poemas reunidos (Hora aberta, 2003), há um poema prosaico que se intitula "Código de Honra" em cujo primeiro item se fala da beleza das mineiras que conheci nos meus 18 anos:

Os sálios, uma tribo dos antigos francos, codificaram um dia as suas leis, conhecidas como "leis sálicas". Muito tempo depois, uma tribo de Goiás, assustada com os bandeirantes (que ameaçaram pôr fogo nos rios) $e$ temerosa das gentes que chegavam de todas as partes, principalmente dos estados limitrofes, organizou o seu código de honra, hoje conhecido por "lei fálica". Vale a pena observar o sense of humor (ou o imutári apucá da língua deles) com que iam distinguindo a procedencia do forasteiro. $O$ documento se encontra num dos bem organizados arquivos paroquiais do Estado. Nós apenas o traduzimos e os separamos em artigos, uma vez que no original era um texto só, com o título de Micoatiára cunhã koty, ou seja, "carta para (ou sobre) as mulheres" [mineira, baiana, piauiense, paraense, matogrossense e tocantinense, sem esquecer a paulista e a carioca]:

I - Se um goiano fizer mal a uma mineira, seja culpado em passar uma semana em Araguari lendo romances de escritor local. 
No mais, um abraço a Nikkolli, cujo nome me lembra a Nicole, uma musa que me abduziu com os perfumes de Paris.

filemd, m.Tel

Gilberto MENDONÇA Teles

331 


\title{
Fortuna crítica da entrevista a $O$ Trem
}

\author{
Oi professor,
}

acabei de ler agora a entrevista. Gostei muito! As perguntas realmente foram instigantes... acho que foram aquelas que o escritor do Jornal Opção gostaria que o O popular tivesse feito. Depois quero 'roubar' mais entrevistas da sua coleção para ler... o jogo que liga sua busca pelo "belo e bom" da poesia, ou melhor na poiética de construir sua aretê e justificar seu sobrenome (como destino teleologicamente construido) ganha um tom diferente quando mostra a inspiração biográfica que traduziu em versos (O Parêntese de Itabira e de um contexto de angústia com a operação de seu filho, a Vida de Planície etc.). Nietzsche estava certo quando intuiu que o lema "conheça-te a ti mesmo" trazia o desafio de "como chegar a ser quem se é": eis a obra como biografia mais verdadeira. Abraço e obrigado por me enviar a entrevista.

MARCOS CARVALHO LOPES

$$
*
$$

Prezado Amigo,

Já passa da uma hora da madrugada; contudo, não poderia deixar de manifestar minha satisfação, acabando de ler sua bela entrevista a "O Trem". Que trem mais bom! (como costumo dizer na espontânea manifestação de meu contentamento). 
Amei suas respostas. Algumas fizeram-me rir; outras, ficar séria, refletindo, concordando, aplaudindo a argumentação arguta, a lucidez e pertinência das ideias.

Encantou-me sua interpretação da "pedra" / "perda" no poema de Drummond. Sou fascinada por esse tipo de coisa.

Mas já é muito tarde. Às 4 h30 devo levantar-me. Estamos madrugando na igreja, numa campanha de oração. Intercederei por você, com muito carinho. Há um elo entre os nossos espíritos. Mistério de Deus.

Um bom restante de noite, um bom dia!

MARIA HELENA GARRIDO SADDI

$*$

Poeta Gilberto, bom dia, mando mais um comentário sobre sua entrevista nO TREM. Esse cara é fisico e escritor, mora ai no Rio. Marcos Caldeira Mendonça

TEÓCRITO ABRITTA

Enviado em: 16/08/2012 21:41:14

Com esta entrevista o TREM revive mais uma vez os Cadernos Literários, trazendo nesta conversa fantástica, com tanta maestria, a riqueza de nossa literatura. 


\section{Olá Giberto,}

Seu amigo(a) Marta visitou o site do Observatório da Imprensa, recomendou que você leia essa noticia e comentou "Entrevista".

"Cachaça ruim essa de Itabira"

Marcos Caldeira Mendonça - 13/08/2012 - 707

Fez triiimmm o telefone do apartamento de Carlos Drummond de Andrade. URL do artigo (clique ou copie e cole em seu navegador): http://www.observatoriodaimprensa.com.br/news/view/ ed707 cacha ca_ruim essa de itabira

Obrigado pelo seu interesse.

$$
*
$$

Gilberto... me deliciei com sua entrevista em O Trem. Histórias incriveis, poemas como sempre lindos... parabéns! Eu tô aqui no Rio ha quase um mês em temporada com meu espetáculo sobre Antonin Artaud.Vou enviar um banner em anexo pra ver se vc se anima e vai ao Teatro me assistir . Vai daqui um abraço. MARCOS FAYAD

$*$

Acabei de ler sua entrevista, como tudo que vc faz está primorosa. Além da saudade que ela me despertou.Beijos ELIANE VASCONCELLOS 
Prezado Marcos, Eu gostaria de receber todas as edições do TREM Itabirano. O conteúdo me agrada muito e achei esplêndida a entrevista do sempre lúcido Gilberto Mendonça Teles, entre outros artigos tão interessantes, como o regaste da memória do nosso grande maestro e pouco reconhecido por muitos, Eleazar de Carvalho, feita pelo novo itabirano Edmílson Caminha. Abraço, MARIA CRISTINA

$$
*
$$

Gilberto!

Só tenho uma palavra para definir essa matéria: excelente! E assim o digo para cobrir bem as perguntas do Marcos e as suas respostas. Um farto e belo material que merece, ao meu ver, ser editado num opúsculo e distribuido entre seus admiradores - primeiro eu, hem! - e estudiosos de letras e literatura de todo o país, mas muito especialmente entre goianos e mineiros - esses irmãos próximos e dóceis, já que constato, a cada oportunidade, que só se é bom goiano se se ama Minas e mineiros (mormente as mineiras).

Admirei, muito, O TREM de Itabira. Se falta, na pátria dromoniana (seria pedante escrever drummondiana?), um governo digno da história, capaz de preservar o patrimônio maior - que vem a ser a História e as referências culturais mais que óbvias, há quem se empenhe em preservar um veículo tão trem-bão dimais da conta, siô! Meus cumprimentos, pois, ao Marcos Caldeira Mendonça (é seu parente, também? Tem liames em Pirenópolis? rsrss). Como ostento uma indisfarçável ponta de orgulho por tê-lo entrevistado há alguns 
anos, orgulho-me mais ainda: um trabalho como este permite-me sentir crescido como leitor e jornalista.

Adorei sua entrevista. Continuo aplaudindo você de pé. Como sempre fiz. Abraços.

ARLETE SENDRA

$$
*
$$

Querido professor Gilberto,

Parabéns pela entrevista que nos proporciona uma viagem pela literária Itabira de Drummond!

É sempre gratificante ler suas produções e suas aulas, nas manhãs de sábado, são sempre lembradas.

Um abraço!

PATRÍCIA DE LUCAS CALDEIRA ROCHA

Obrigada, Gilberto querido. Ler seus textos é sempre um prazer e um aprendizado. Um grande abraço,

THEREZINHA MUCCI XAVIER 
Obrigada, amigo Gilberto.

Suas entrevistas têm a sua marca registrada: sempre se aprende com elas. E há uma leveza muito sua. Um certo Saci, rindo à socapa, como já disse, de forma um pouco melhor, ao fim de $\mathrm{O}$ redemoinho do lírico. Especial para o Jornal Opção, no último número, saiu o ensaio "A cumplicidade entre Carlos Drummond e Gilberto Mendonça Teles". ssina Marcos Carvalho Lopes. Creio que é aquele moço inteligente de Jatai de que você me falou. Ele escreve bem. Este ensaio aparece também no site da UBE. Parabéns e obrigada. Continue fazendo sucesso. Não adianta fechar uma porta, tal como você já disse.

Grande abraço.

$$
\text { DARCY [FRANÇA DENÓFRIO] }
$$

$$
*
$$

Caríssimo Gilberto, Li a entrevista e adorei. Vou passá-la ao meu grupo de pesquisa de Poesia, e certamente vamos tirar muito proveito do texto. Obrigada, e grande abraço,

MELÂNIA [SILVA AGUIAR]

$$
*
$$

Gilberto, gostei demais desta entrevista. Da próxima vez que for na minha Muriaé, trago-lhe uma cachaça que jamais esquecerá. Beijos.

MARCIA BARROCA - Sexta-feira, 17 de Agosto de 2012, 16:14 
Caro Editor Marcos Caldeira, boa tarde! Quero cumprimentálo pela excelente entrevista com o Poeta e Crítico Literário Gilberto Mendonça Teles. Acabei de lê-la; o jornal me foi repassado, via e-mail (PDF), pelo próprio Gilberto. Atenciosamente, FRANCISCO PERNA FILHO

$$
*
$$

Caro Gilberto, Agradeço a gentileza de enviar-me O Trem Itabirano. Li e reli sua entrevista - um primor de sensibilidade, erudição e ironia. Parabéns.

Cordialmente,

LENA CASTELLO BRANCO

$*$

Meu querido professor,

li toda a entrevista e dei risada lembrando-me do episódio do Cyro dos Anjos. Falamos dele no dia que almoçamos ai no Rio, lembra? Eta goiano arretado. Sabe que eu também gostaria de conversar com Manuel Bandeira? Gostaria de lhe contar que adoro o poema Porquinho-da-Índia. Nunca vi um poeta definir com tamanha propriedade e simplicidade o zelo caprichoso do amor. Sabe que a entrevista me aguçou a vontade de um conversê? E para rimar, um beijo grande pra vosmecê. Ia me esquecendo: Parabéns! HELOÍSA [HELENA DE CAMPOS BORGES] 


\section{Gilberto,}

que bom um email seu! Tem passado bem? Um abraço enorme, da sua amiga portuguesa, Sara.

$$
*
$$

Prezado Professor Gilberto,

ainda bem que o senhor teve tempo de avisar ao Poeta sobre a ruindade da cachaça. É crime hediondo falsificar tão preciosa bebida. E que história maravilhosa a da sua abdução para o planeta Attynk e chá das cinco com a etezinha Nikolli, curiosíssima sobre o nosso país. Uma amiga minha quase foi abduzida numa madrugada na Cidade do México. O disco voador passou baixinho ao lado dela mas o marido teve tempo de dar-lhe um puxão e evitar o voo interplanetário. O que foi uma pena. Que jornal interessante. Que colaboradores . Obrigada por se lembrar de mim. Grande abraço

$$
\text { * SOCORRo [EVELYN] }
$$

Caro Gilberto,

Ótima entrevista e bom texto de apresentação do entrevistador.

Não sei se já lhe disse, comprei seu Vanguada Europeia \& Modernismo Brasileiro e GOSTEI DEMAIS pelo duplo prazer de juntar o útil do saber com o agradável da leitura. É leitura recorrente. Abração !!!

VARIO DO ANDARAY 
Professor Gilberto, Li sua entrevista com um prazer enorme. Senti orgulho de você e também muita saudade. Um abraço, Belinha [ISABEL DIAS-NEVES]

$$
*
$$

Estimado Gilberto:

Le agradezco enormemente por enviarme la entrevista. Ya mismo comienzo a leerla. Si está de acuerdo, en el transcurso de la semana le escribo para acordar el próximo encuentro y conversar sobre la fecha de entrega del trabajo final. Me enviaron, desde Rosario, una copia del poema que González Tuñón escribió dedicado a Prestes, asi que estoy trabajando en eso. Muchos saludos, MARÍA FERNANDA. [de Rosário, Arg.]

Gilberto! Que entrevista boa de ler!!! Parece que eu estava na sala com você! [Lúcia Kury]

$$
*
$$

Meu Mestre querido, como aprendo com o senhor! Que aula sobre Drummond... Que linda entrevista. À parte isso, como me ri dos poemas presos na parede do quarto da prostituta! E como me ri também de sua pronta resposta a Cyro dos Anjos - embora não me tenha causado qualquer espécie de estranheza -, quando de seu primeiro encontro com ele na Universidade de Brasília... Pensei: 
este, sim, é e sempre será o "meu" Mestre. Aliás, tomei a liberdade de enviar essa entrevista para um sem número de pessoas. Desculpe-me por não lhe ter pedido licença antes. Parabéns, Mestre. Sua lúcida inteligência está sempre a nos surpreender. NILCE [RANGEL DEL RIO]

$$
*
$$

Eita menino sumido, credo! Está 'de mal', é? Pergunto sempre à Fátima e ao Fábio Henrique por você. E então, tudo bem, muito trabalho, viagens...?

Olhe, Gilberto, honra-me demais ser sua amiga (se o tenho como tal, aí, já é outra coisa), pois sempre o considerei minha referência literária, especialmente, como poeta. 'Macaca de auditório', ou melhor, 'macaca de livro', mesmo, sempre e sempre, fui. Por isso, a cada sucesso seu, orgulho-me ainda mais, e minha torcida é permanente. Não desisti de vê-lo na ABL, hem?! / E essa entrevista, criatura, que maravilha! Respostas fantásticas, bom humor, o conhecimento à mostra, enfim, digna de um Gilberto Mendonça Teles. Você é mestre no que faz. Até nas entrevistas. PARABÉNS! Imprimi todo o texto e guardei-o até como fonte para futuras pesquisas.Quando vier a Goiânia, apareça. Enquanto isso, apareça aqui mesmo. Umas semana venturosa. Beijão. LEDA [SELMA] 
Olá, Gilberto, caro amigo, muito lhe agradeço o envio de $O$ TREM. Li, com interesse e proveito, sua entrevista, e outros textos. Conheci um pouco mais do maestro Eleazar de Carvalho.

Foi interessante ler Cyro dos Anjos em livros emprestados por você, quando fora sua aluna. A entrevista me fez lembrar deste tempo. Felicito-o por esta diferente e diferenciada entrevista. Surpresas e revelações. Algumas curiosidades sobre Minas. Um pouco mais do que imaginamos saber de seu estilo, de sua obra, da vida. Parabéns, Gilberto. Abraço fraterno, ALICE SPINDOLA

$$
*
$$

Prezado Professor Gilberto, tudo bem? Obrigado pela edição do jornal. O Marcos Caldeira tem razão: craque é craque! Enviei um e-mail para o senhor há alguns dias. Entreguei os documentos na PUC na última semana. Porém, recebi um telefonema da Daniele, secretária do Departamento de Letras, solicitando que todas as vias do projeto sejam rubricadas pelo senhor. Fui informado que o pós-doutorado pode ser solcitado agora, mas que os trâmites ocorrerão somente a partir de outubro. Portanto, não temos pressa, mas quando o senhor puder, alterarei o cronograma do projeto, em função das novas datas, e levarei para o senhor rubricá-lo. Aproveito para lembrá-lo sobre as indicações de bibliografias sobre literatura de cordel (poética) e sobre retórica. Lembro também sobre um outro estudo a respeito da Gramatiquinha da Fala Brasileira, além daquele da Edith Pimentel Pinto. Um abraço, ALBERTO ROICE 
gilberto, meu querido, obrigada pelo jornal e sua bela entrevista, vou espalhar por aqui também. abraço, GOIANDIRA ORTIZ

$$
*
$$

Clevinha não deixe de ler - e de se divertir - com a entrevista de meu Mestre Gilberto Mendonça Teles. Está nas últimas páginas do jornal. Aliás, quando vocês vierem aqui, vou chamá-los (a Gilberto e Maria) também.

NILCE [RANGEL DEL RIO]

$$
*
$$

Olá Gilberto, tudo bom? Li a saborosa entrevista. Linda a história do transplante de córneas. Um abraço Iuri Pereira

$$
*
$$

Un grand merci pour ce mail e um abraço, até logo, Alain [Faudemay]

$$
*
$$


Gilberto, gostei muito da sua entrevista para O Trem itabirano, considerações inteligentes e histórias interessantes. Obrigada e abraços na Maria.

Astrid [Cabral]

$$
*
$$

Amigo Gilberto: alegria receber a sua excelente entrevista, que li prazerosamente, inclusive para melhor conhecer a vida do poeta e do homem gilberto mendonça teles. quanto tempo, amigo! quando vem por estas bandas? estou à disposição. fim deste ano ou meados do próximo deverei estar lançando um novo livro. aguarde-o. receba, juntamente com todos os seus, o abraço do Sérgio Castro Pinto

$$
*
$$

Gilberto, bom dia, saudades.Obrigada pelo O TREM que muito nos interessou. Bjs carinhosos. Lucilene [Maciel]

Querido Gilberto. Agradeço-lhe muito ter enviado esta edição do jornal itabirano. Estou lendo aos poucos, saboreando. Mas já li a sua entrevista, na qual v. se mostra tão humano e, ao mesmo tempo, tão diferente, como criador privilegiado que é. Assim matei a saudade de - você e de nosso itabirano maior, do qual você é o portavoz privilegiado. Um grande abraço de sua sempre discípula Thereza [Christina] 
Querido Gilberto: Muitos parabéns! Adorei! Gostei muito do seu email, até porque há muito não tinha noticias suas. Eu continuo também a escrever,o meu romance mais recente saiu em 2011,chamase A Cidade de Ulisses e é uma história de amor passada em Lisboa. Saiu também entretanto em E-Book acessível no Wook. No meu novo site (ainda em construção) está uma entrevista na TV sobre o livro, penso que seria interessante para os alunos. Está em: www.teolindagersao.wordpress.com Um grande abraço de parabéns para si e espero que até breve! Vá dando notícias quando puder! Teolinda [Gestão], Portugal

$$
*
$$

Muito bonito. É sempre bom conhecer um pouco mais do universo daqueles que admiramos. Abraço, Adriano Curado Pirenópolis.

$$
*
$$

Em 1 de setembro de 2012 11:22,

\section{<tanussicardoso@uol.com.br>escreveu:}

Meus amigos, o Trem veio lotado de gente boa e matérias com jeitão de "trem bão". Parabéns. Qualquer dia, perco a inibição e a preguiça e envio alguns poemas pra esse trenzão, ok? Muito feliz com a entrevista do Gilberto Mendonça, grande Mestre de todos nós! A entrevista correu solta e as perguntas e as respostas fluíram com gosto de quero mais. Parabéns de novo. Também a toda equipe do "Trem Itabirano" que, a cada dia, se torna mais brasileiro. Abração do Tanussi Cardoso 


\section{MESTRE}

A Gilberto Mendonça Teles,

que sabe o rio e o $x$ do poema.

Mestre é quem sabe o rio e suas curvas,

o ponto e suas linhas, na reta e na paralela

do sertão com seu silêncio de mapa e jejum.

Mestre é quem sabe a carta e seus rabiscos

e atravessa a letra escura e enluara a sombra

e o vulto na amplidão do vau e da pinguela.

Mestre é quem sabe o caminho e a pedra no meio da cruz e suas direções de pregos e martelos segundo o verbo e a dor do calvário.

Mestre é quem sabe que no meio do grifo há um bico e um $X$, mas entalha a viagem a centro do círculo e do signo de sete pontas.

Mestre é quem sabe as palavras, as reticências e seus seixos na incerteza do meio e do fim, mas marca as direções e os quatro ventos.

Mestre é quem sabe o deserto e sua areia, os grãos e os horizontes vermelhos da distância e chega junto ao destino de deuses e de homens.

Mestre é quem sabe o menir e sua viagem de sol e sombra e vultos e mistérios pela alma da formas e percorre as veredas e atravessa a pedra além. 


\begin{abstract}
Mestre é quem vê a caverna e sua noite
e cinzela o boneco e seus riscos no barro

e no caráter para ser imagem e pó do tempo.
\end{abstract}

Goiânia, 30-5-2004.

José Fernandes. 